Magdalena WANIEWSKA

Katolicki Uniwersytet Lubelski

\title{
Mienie i nadzór samorządu stanowego wsi piastowskiej
}

Samorząd jako samoczynna forma organizacji życia publicznego towarzyszy człowiekowi w różnych formach, od początku jego trwania w społeczeństwie, dowodząc tym samym, że jest instytucją sprawdzającą się w różnych ustrojach. Był on charakterystyczny zarówno dla społeczeństw przed-państwowych, jak i późniejszych, dostosowując się do roli i celu państwa w konkretnym okresie historycznym. Pojawiał się w okresach rozkwitu demokracji, a zanikał w okresach despotyzmu i silnego aparatu państwowego.

Zasadniczym celem tej pracy jest określenie dwóch elementów teorii samorządu stanowego wsi - mienia i nadzoru tej instytucji życia lokalnego. Stanowi ona drugą cześć artykułu, w którym podjęte zostały zagadnienia zadań i kompetencji samorządu wiejskiego ${ }^{1}$. Całość jest zaś próbą podsumowania tego, co do tej pory zostało powiedziane na temat średniowiecznego samorządu wsi.

Problematyka samorządu jest zagadnieniem ważnym szczególnie w okresie weryfikacji instytucji lokalnych i szukania dla nich nowych dróg rozwoju. Wśród rozważań nad efektywnością obecnych samorządów, pomocny może być bowiem ogląd wcześniejszych form jego istnienia zwłaszcza samorządu stanowego, jako instytucji sprawdzającej się w trudnej sytuacji politycznej i mającej wyniki gospodarcze, administracyjne czy wojskowe. Zrozumienie mechanizmu działania tej instytucji w okresie przekształceń ustrojowych może stanowić inspirację dla współczesnych struktur lokalnych, podejmujących postulaty zmniejszenia bądź rozszerzenia zakresu gospodarczego, skutecznego nadzoru i kontroli instytucji samorządowych, efektywnej koordynacji zadań podejmowanych przez wspólnoty lokalne oraz aktywizacji obywatelskiej.

1 M. Waniewska, Samorzad stanowy wsi w Polsce piastowskiej. Zadania i kompetencje, „Roczniki Nauk Społecznych” TN KUL 2001, z. 1. 
Artykuł ten ma wykazać, iż właśnie przez czynnik ekonomiczny funkcjonowanie samorządu stanowego zabezpieczyło interesy wspólnoty wiejskiej. Podobieństwo pomiędzy samorządem średniowiecznym a współczesnym samorządem państwowym, dotyczy wyłącznie zakresu działalności administracyjnej i gospodarczej ${ }^{2}$.

Powrót do przeszłości - przy użyciu metody historyczno-krytycznej jest konieczny nie tylko do poznania koncepcji początków samorządu, ale także do teoretycznego określenia drogi, jaką przeszła wspólnota samorządowa w tworzeniu własnych organów, a przede wszystkim określenia przyszłego kształtu samorządu państwowego. Szerokie spojrzenie na problematykę samorządu, uzyskane przez analizę jego poszczególnych typów pozwala dostrzec charakter i intensywność zmian, którym ulegał dostosowując się do aktualnej sytuacji politycznej i społecznej.

Za podstawowy materiał źródłowy tej pracy należy uznać publikacje Stefana Inglota z zakresu historii średniowiecza i struktury ówczesnej wsi, zwłaszcza zaś jego najbardziej znaną monografię - Historię chtopów polskich, w perspektywie poglądów J. Bardacha, A. Świętochowskiego, K. Buczka, K. Modzelewskiego, R. Grodeckiego, H. Łowmiańskiego, K. Tymienieckiego, S. Wójcika i innych.

W średniowiecznym państwie polskim ścierały się dwa przeciwstawne kierunki: centralizacyjny, reprezentowany przez monarchę i decentralizacyjny, oparty na funkcjonującym prawie dziedzicznym i działalności przeciwstawiającej się ekspansji terytorialnej władcy. Ówczesne rozbicie jedności państwowej przeniosło punkt ciężkości z kwestii politycznych na wewnętrzne sprawy społeczeństwa piastowskiego. W tym czasie kwestie społeczne związane z ustrojem feudalnym i przekształceniami ekonomiczno-prawnymi zaabsorbowały stany społeczne w takim stopniu, jak polityka zagraniczna w okresie tworzenia państwa. Dodatkowo na XII wiek przypadł $\mathrm{w}$ państwie polskim okres znacznej poprawy sytuacji społeczno-materialnej i prawno-administracyjnej ludności wiejskiej. Działo się to na skutek ówczesnego rozwoju stosunków gospodarczych i politycznych, które doprowadziły do utworzenia społeczeństwa stanowego i ich instytucji przedstawicielskich. Aspiracje do współzarządzania państwem, zwłaszcza w sprawach lokalnych, charakteryzowały wszystkie

2 Realizowana przez samorząd średniowieczny działalność sądowa i polityczna wykonywana jest współcześnie przez inne organy państwa. 
ówczesne warstwy społeczne, a chęć zwiększenia własnych uprawnień, a przez to uzyskania lepszego statusu społecznego były znamienne zwłaszcza dla grup, znajdujących się na najniższych szczeblach drabiny społecznej.

Ustalenie średniowiecznego mienia jest dla badaczy kwestią skomplikowaną. Własność faktyczna w ówczesnym państwie polskim nie zawsze, bowiem, odpowiadała stanowi prawnemu. Posiadanie mienia mogło być poparte prawem bądź stanowić akt przestępczy. Ze względu na to, iż wielkość dóbr stanowiła w ustroju feudalnym o pozycji społecznej, w państwie piastowskim na porządku dziennym było zajmowanie cudzej własności siłą. Mimo tego, iż bezprawne przywłaszczenie dóbr podlegało kontroli sądowej $^{3}$, walki zbrojne - charakterystyczne dla okresu niepokojów wewnętrznych - sprzyjały przechodzeniu własności z jednych rąk w inne.

W okresie panowania Piastów pojęcie własności w pełnym znaczeniu obejmowało posiadanie, użytkowanie i rozporządzanie, czyli ogólnie władanie określoną rzeczą. Na skutek umacniania się stosunków feudalnych pojęcie własności przypisane było niejako do ziemi. Pojęcie ziemi, bowiem obejmowało w sobie zarówno grunt, osiadłą na niej ludność, jak również znajdujące się $w$ jej granicach ruchome i nieruchome dobra ${ }^{4}$. W omawianym okresie na pierwszy plan w życiu społecznym i gospodarczym wysunęło się rolnictwo i jego interesy, spychając na plan dalszy handel czy przemysł. W społeczeństwie, w którym „wieś była wszystkim”, ziemia stanowiła treść życia, była podstawą istnienia i podstawowym atrybutem władzy.

Ustrój feudalny wprowadził możliwość istnienia dwóch form własności w odniesieniu do jednego dobra. Na mocy prawa określona własność przyjmowała charakter własności pełnej, czyli zwierzchniej oraz własności użytkowej, sprowadzającej się do dzierżawy. Prawo do własności rzeczywistej przysługiwało stanom uprzywilejowanym. Oznacza to, iż chłopi jako ludność poddańcza, posiadali tylko uprawnienie do użytkowania (określonej wolą pana) własności.

3 Pan obawiający się najazdu na własne ziemie ustalał zakład - kwotę, którą trzeba było zapłacić po zajęciu gwałtem jego dóbr. Por. J. Bardach, B. Leśnodorski, M. Pietrzak, Historia ustroju i prawa polskiego, Warszawa 1998, s. 137-138.

4 Por. H. Łowmiański, Przemiany feudalne wsi polskiej do 1138 r., „Przegląd Historyczny" 1974, z. 3, s. 437; K. Tymieniecki, Historia chłopów polskich, Warszawa 1965 , t. 1 , s. $179-180$. 
Literatura dotycząca wiejskiej organizacji chłopów stanowi swoistą dyskusję na temat charakteru posiadanych przez nich uprawnień do ziemi. Kwestia sporna dotyczy tego, czy chłopi posiadali wówczas pełne prawo do ziemi i dopiero wraz z rozwojem ustroju poddańczego utracili je na rzecz jednostek bardziej uprzywilejowanych, czy też zawsze posiadali wyłącznie możliwość dzierżawy gruntu.

Według S. Inglota, część ludności wiejskiej z czasów wspólnot opolnych posiadała pełne prawo do ziemi. Własność ta, miała charakter pierwotny, bądź pochodziła z nadania. Śladem tej ludności w okresie zmian ustrojowych byli, tzw. „dziedzice”, którzy w połowie XII w. utracili swą niezależność i popadli w poddaństwo ${ }^{5}$. Odmienne stanowisko prezentują m.in. K. Buczek i R. Grodecki, zdaniem których chłopi nigdy nie posiadali pełnej własności ziemskiej i zawsze ,siedzieli na cudzej ziemi"6.

Mienie w okresie średniowiecza można było nabyć zgodnie z ówczesnym prawem przez: zawłaszczenie, zasiedzenie, jako zdobycz wojenna, na mocy prawa nabrzeżnego lub też na skutek przeniesienia prawa do własności na inną osobę. Zawłaszczenie dokonywało się przez zajęcie i stałe użytkowanie dobra porzuconego lub nie będącego niczyją własnością. W wypadku, gdy posiadanie dotyczyło własności nieruchomej np. ziemi, ale odbywało się przez określenie długi czas, uprawomocniało zajęcie cudzych dóbr jako zasiedzenie. Przeniesienie prawa do określonej własności odbywało się trzema sposobami: przez spadek, nadanie lenna lub umowę ${ }^{7}$.

Własność sukcesyjna należała do własności podzielnej, według zasad prawa spadkowego. W kwestii dziedziczenia, w państwie polskim istniał podział na tzw. macierzyste i ojczyste. W gminach dobra ojczyste dziedziczyli wszyscy synowie po równo, zaś spadek po matce obejmował także córki. W przypadku, gdy nie było osób, którym przysługiwało prawo do spadku, majątek przechodził na własność władcy ziem, tworząc tzw. puściznę ${ }^{8}$.

5 Historia chłopów polskich, pod red. S. Inglota, Wrocław 1992, s. 28; por. S. Inglot, Historia społeczna i gospodarcza średniowiecza, Wrocław 1949, s. 135; S. Inglot, Historia gospodarcza. Zarys dziejów: starożytnych, średniowiecznych, nowożytnych, nowoczesnych, Wrocław 1949, s. 97.

${ }^{6}$ K. Buczek, Uwagi o prawie chłopów do ziemi w Polsce piastowskiej, „Kwartalnik Historyczny" 1957, z. 3, s. 94; R. Grodecki, Zagadnienia feudalizmu w Polsce, Kraków 1930, s. 18.

7 J. Bardach, op. cit., s. 141-142.

${ }^{8}$ Ibidem, s. $146-147$. 
Zasada dzielenia majątku pomiędzy wszystkich potomków, miała zastosowanie przede wszystkim w warstwach bogato uposażonych. W przypadku niewielkich gospodarstw kmiecych, dzierżawa zazwyczaj przechodziła w ręce najstarszego syna, podczas gdy większą sukcesję dzielono pomiędzy kilkoro dzieci. Los pozostałych dziedziców (jeżeli tacy byli) zależał od woli pana. Mógł on przyznać im ziemię nadziałową wydzieloną z ziem własnych (posiadłości dworskiej) lub z ziem nie uprawianych. Chłopi pozbawieni prawa do spadku zasilali grupę ludności bezrolnej, a w najgorszym wypadku opuszczali wieś ${ }^{9}$.

Możliwość zarządzania własnością dziedziczną przez feudała była ograniczana dążeniami krewnych. Gwarancję ochrony ich interesów dawały: prawo bliższości, pierwokupu i retaktu. Pierwsze dotyczyło wyłączenia od własności dóbr dziedzicznych, osób posiadających mniejsze uprawnienia, drugie - sytuacji zamiaru zbycia tych dóbr, trzecie było konsekwencją złamania prawa pierwokupu. W wypadku sprzedaży właściciel zobowiązany był do zaproponowania kupna ziemi krewnym. Jeżeli tego nie uczynił, odzyskiwali oni dobra po uiszczeniu kwoty, za którą ów właściciel je nabył ${ }^{10}$.

Normą, która osłabiła dążenia pana do swobodnego dysponowania ziemią nadziałową, było również tzw. prawo zakupne. Według niego, pan nie mógł usunąć kmiecia z ziemi, ani odebrać mu jej, bez wypłaty określonego odszkodowania. Wysokość rekompensaty równała się sumie, którą uiścił chłop za ziemię, osiedlając się we $\mathrm{wsi}^{11}$.

Zagadnienie uposażenia piastowskiej gminy wiejskiej jest tematem spornym, trudnym do przedstawienia, a jednocześnie w wyniku uogólnienia, przedstawianym w sposób fragmentaryczny. Bogata literatura dotycząca form własności feudalnej, nie daje jednoznacznej odpowiedzi, co należało do wsi jako wspólnoty terytorialnej, co zaś pozostawało indywidualną własnością jej mieszkańców.

Pojęcie wspólnoty samorządowej przysługiwało wsiom lokowanym na prawie niemieckim i tym jednostkom, które przyjęły ustawodawstwo zachodnie. Nie znaczy to, że cała ziemia i dobra materialne wchodzące w skład wsi stały się z chwilą lokacji własnością średniowiecznego samorządu. Jako korporacja mógł on posiadać mienie i własny dochód, jed-

9 S. Inglot, Historia społeczna, s. 108.

10 J. Bardach, op. cit., s. 140; M. Gończar, Samorzad wsi historia i nowe możliwości, Warszawa 1990, s. 11.

11 S. Inglot, Historia społeczna, s. 154. 
nakże prawa samorządu do tego uposażenia, nie mogły wykraczać poza istniejące prawo własnościowe.

Działalność instytucji samorządu ograniczona była wolą pana do wąskiego zakresu działalności sądowniczej i kontrolnej nad chłopami. Odmienna sytuacja miała miejsce w przypadku jego mienia i dochodów. Uposażenie samorządu wynikało częściowo z przyzwolenia pana feudalnego, częściowo zaś było wynikiem prawa zwyczajowego. Wydaje się jednak, iż jak w przypadku chłopów, prawo do własności samorządu, jak i możliwość powiększenia ziemi były znacznie ograniczone.

Zakres mienia samorządu wiejskiego, zdaniem S. Inglota, uzależniony był od podziału, jakim podlegały wielkie własności ziemskie. Pan feudalny z własnych dóbr ziemskich wyznaczał tzw. ziemię pańską (dworską) i trzy mniejsze obszary (stanowiące jednostkę wiejską), a mianowicie: dzierżawy chłopskie, dzierżawy innych osób i tzw. wspólne użytki, w skład których wchodziły lasy, pastwiska i łąki ${ }^{12}$.

Według tego autora, wspólnota użytków wywodziła się z prasłowiańskiego równouprawnienia wszystkich mieszkańców do własności wspólnej, swoistej dla okresu rodowego i początkowego stadium wspólnoty opolnej $^{13}$. Nie znaczy to jednak, że w państwie piastowskim wszystkie łąki czy pastwiska stanowiły mienie wspólne.

W okresie umacniania stosunków feudalnych, panowie dążyli do posiadania szerokiego majątku wyłącznie na własny użytek. W skład tych obszarów wchodziły zarówno pola pańskie, jak i lasy, łąki oraz pastwiska, należące do własności indywidualnej feudała i odgrodzone wyraźnie od ziemi ludności poddanej ${ }^{14}$. Należy przyjąć, iż uposażenie gminy wiejskiej ograniczało się do ziem zbiorowych, leżących wyłącznie w jej granicach.

Odmiennego zdania, co do genezy stworzenia wspólnych użytków jest K. Tymieniecki. Dla niego wywodzenie wspólnych ziem z pierwotnego porozumienia mieszkańców jest efektem błędnego - bo opartego na domysłach - wnioskowania, jak również skutkiem przywiązania do koncepcji umowy społecznej ${ }^{15}$.

M. Gończar statut własności gminnej przyznał przede wszystkim ziemiom, które pozostawały we wspólnym użytkowaniu ogółu kmieci, ale

12 Ibidem, s. 107-108.

13 Historia chłopów, s. 11.

14 S. Inglot, Historia społeczna, ibidem.

15 K. Tymieniecki, Z metodyki nad starożytnościami słowiańskimi, „Przegląd Historyczny" 1948 , s. 7. 
nie wchodziły w skład ich nadziału (pola, domostwa i zagrody) ${ }^{16}$. Definicja ta wydaje się być zbyt ogólna, ponieważ jak wykazał Inglot, we wsi znajdowały się nadziały będące własnością innych grup ludności.

Za ziemie samorządu wiejskiego S. Inglot uznał tzw. tereny niezajęte, objęte prawem wspólnego użytkowania. Oznacza to, iż pojęcie mienia gminy obejmowało tereny wspólnych użytków i pasa ziemi ornej leżącej ugorem (zarówno z dzierżaw kmieci, jak i innych właścicieli nadziałów $)^{17}$. Użytkowanie ziemi samorządu przysługiwało wszystkim mieszkańcom wsi i samemu panu feudalnemu, zgodnie z zasadami ustalonymi $\mathrm{w}$ umowie, zawartej wcześniej między obiema stronami ${ }^{18}$.

Trudno określić wielkość ziemi należącej do ówczesnego samorządu wiejskiego. Zależała ona od wielkości wspólnych użytków wsi, a zwłaszcza obszaru pastwisk na polach uprawnych.

Okres kolonizacji i osadnictwa, przejścia od prawa rodzimego (polskiego) na prawo niemieckie przyniósł ze sobą poprawę sytuacji ludności nieswobodnej (z wyjątkiem służby dworskiej), która uzyskała prawa chłopów wolnych ${ }^{19}$. Ujednolicenie statusu prawnego chłopów wynikało z odgórnych działań ówczesnej administracji państwowej, wzmocnionych prawdopodobnie dążeniami wiejskich samorządów stanowych. W państwie Piastów, bowiem regulacje prawne obejmujące całe warstwy społeczne, były często skutkiem praktyki, funkcjonujących ówcześnie stanowych instytucji.

W nowych warunkach o statusie społecznym ludności wiejskiej, wyznaczanym przynależnością do określonej grupy chłopów, decydowały: wielkość i produkcja gospodarstwa.

Gospodarcze i społeczno-ustrojowe przemiany piastowskiej wsi oprócz pozytywnych zmian w sytuacji ludności (unormowane świadczenia, większe prawa, samorząd) przyczyniły się do większego zróżnicowania w samej warstwie kmieci. Sprzyjał temu schyłek działalności kolonizacyjnej i osadniczej, wzrost ludności wiejskiej i zapotrzebowanie na ludność najemną (także do gospodarstw kmiecych).

${ }^{16}$ M. Gończar, op. cit., s. 12.

17 S. Inglot, Historia spoleczna, s. 108-109; J. Bardach, op. cit., s. 139.

18 Umowa dworska określała rodzaj i liczbę zwierząt wypasanych na wspólnych pastwiskach, ilość i przeznaczenie drewna z lasu oraz rodzaj i sposób uprawy tych obszarów; S. Inglot, Historia społeczna, ibidem.

19 M.in. R. Grodecki, Zagadnienia, s. 19; R. Heck, Okres gospodarki czynszowej (od połowy XIII do schytku XV w.), w: Historia chłopów polskich, t. 1, pod red. S. Inglota, Warszawa 1970, s. 181-182. 
Wśród ludności wolnej w początkowym okresie osadnictwa i tworzenia nowych wsi wyróżniano przede wszystkim: miejscowych i tzw. wolnych gości. Pierwsi stanowili ludność od dawna osiadłą na ziemi i wraz $\mathrm{z}$ nią podporządkowaną panu, drudzy osiedli w danej wsi na podstawie umowy czynszowej, przenosząc się z innych włości ${ }^{20}$.

Po okresie XIII-wiecznych przemian ustrojowych, na podstawie zamożności, której wyznacznikiem była wielkość posiadanego uposażenia i zakres uprawnień, wśród wieśniaków wyróżniano: sołtysów, kmieci, zagrodników, chałupników, komorników, czeladź dworską i rzemieślników ${ }^{21}$.

Grupa sołtysów górowała nad pozostałymi większym gospodarstwem (ponad 2 łany), dochodami z czynszów, sądownictwa i dodatkowego uposażenia $^{22}$. Na mocy dokumentu lokacyjnego sołtys otrzymywał nadział kilkakrotnie (od 2 do nawet 10 razy) większy niż nadział kmieci. Najczęściej obejmował on obszar około 1/10 terenu wsi. Mógł on dodatkowo założyć na nim karczmę, młyn, warsztat rzemieślniczy, rzeźnię lub staw. Za własną ziemię sołtys nie był zobowiązany uiszczać żadnej daniny. Mógł za to czerpać dochody z leśnych barci, połowów i polowań. W ramach dochodów płynących z jego stanowiska przysługiwało mu prawo do 1/6 czynszów ściaganych na rzecz pana oraz 1/3 części kar sądowych. Gospodarstwa sołeckie miały charakter dziedziczny, a objęte były tzw. prawem zakupnym, gwarantującym sołtysom odszkodowanie za zajęcie go przez pana ${ }^{23}$.

Aż 80\% ludności wiejskiej stanowili kmiecie, których nadział ziemi kształtował się w zależności od gatunku ziemi od ćwierci łanu do 2 łanów. Mieli oni prawo do dziedziczenia ziemi i sprzedaży jej za zgodą pana. Dodatkowym uprawnieniem kmieci było odszkodowanie wypłacane przez pana, gdy ten chciał pozbyć się jakiegoś kmiecia z własnych ziem² ${ }^{24}$. $\mathrm{W}$ tym okresie to właśnie grupa kmieci, ze względu na posiadane przez

20 M.in. K. Modzelewski, Chłopi w monarchii wczesnopiastowskiej, Wrocław 1987, s. 54, 116-118.

${ }^{21}$ Historia chlopów, s. 32; R. Heck, op. cit., s. 184-188. Oprócz powyższych grup istniał jeszcze jeden rodzaj chłopów, stanowiący grupę pośrednią między kmieciami a szlachtą. Byli to włodycy, wywodzący się z osiadłego na własnej ziemi rycerstwa. Por. S. Grabski, Myśli o dziejowej drodze Polski, Warszawa 1989, s. 106-107.

22 S. Inglot, Historia gospodarcza, s. 105; S. Inglot, Historia spoleczna, s. 154; J. Bardach, op. cit., s. 45; M. Gończar, op. cit., s. 12; R. Heck, op. cit., s. 172.

${ }^{23}$ Historia chlopów, s. 32.

${ }^{24}$ Ibidem, s. 33. 
nią prawa wolnościowe i prawo do samorządu uważana była za rzeczywistą ludność chłopską, utożsamianą z reformami ówczesnej wsi.

Podstawą prowadzenia samodzielnego gospodarstwa $\mathrm{w}$ okresie feudalnym było posiadanie własnych narzędzi rolniczych. Podział warstwy chłopskiej na grupy, uzależniony był przede wszystkim od rodzaju sprzętu, jakim dysponowali. Ze względu na obszar zagospodarowanej ziemi, wśród kmieci wyróżniano chłopów wielko-, średnio- i małorolnych. Grupie tej przeciwstawiano pozostałą ludność wiejską, podzieloną na warstwy ludności bezrolnej i bezdomnej ${ }^{25}$. Podział na grupę wieśniaków wielko- i średniorolnych odpowiadał ilości zwierząt używanych przez nich jako siły pociagowej, czyli sprzężajowi w gospodarstwie. Chłopów małorolnych i bezrolnych wyróżniano w zależności od tego, czy cudzym sprzężajem uprawiali ziemię własną (małorolni), czy innego chłopa (bezrolni). Ostatnią wyróżnianą warstwą byli tzw. komornicy - najbiedniejsza grupa chłopska, nie posiadająca własnej chałupy - ludność „siedząca na komorze u innych mieszkańców"26.

Nowe kryteria podziału warstwy chłopów, mające wyraz w przeniesieniu środka ciężkości z kwestii posiadanych przez chłopów uprawnień wolnościowych na kryteria ekonomiczne były skutkiem ujednoliceń prawnych oraz wynikiem rozwoju gospodarki wiejskiej i wzmożonej działalności handlowej. Przekształcenia te dokonane w wyniku dopasowania do funkcjonujących ówcześnie instytucji wiejskich, nie tylko zunifikowały chłopów pod względem prawnym, ale przyczyniły się do stworzenia w tej warstwie silniejszego poczucia własnej tożsamości.

Wśród ówczesnych gospodarstw przeważały nadziały łanowe ${ }^{27}$, chociaż spotkać można było zarówno mniejsze półłanowe, ćwierćłanowe i kilkumorgowe $^{28}$ gospodarstwa (zagrodników, rzemieślników wiejskich) ${ }^{29}$, jak i wyżej wspomniane gospodarstwa kilkułanowe. Nadziałem chłop mógł rozporządzać tzn. sprzedać go lub zamienić na inny, wyłącznie za

25 Ibidem.

${ }^{26}$ K. Tymieniecki, Historia chlopów, s. 217, 264.

27 Średniowieczny nadział chłopski (łan) we wsiach na prawie niemieckim wynosił od 16,8 ha (łan chełmiński) do 24,2 ha (łan frankoński); S. Wójcik, Samorzad terytorialny w Polsce w XX wieku. Myśl samorzqdowa Historia i wspótczesność, Lublin 1999 , s. 40.

${ }^{28}$ Łan chełmiński wynosił ok. 30 morgów ziemi. Por. K. Tymieniecki, Procesy twórcze formowania się społeczeństwa w wiekach średnich, Warszawa 1921, s. 218-219.

29 S. Inglot, Historia spoleczna, s. 108, 154; S. Inglot, Historia gospodarcza, s. 105 . 
zgodą pana. Jeżeli przejście własności nadziału z rąk jednego chłopa w ręce innego, odbywało się w ramach jednej gminy, mienie wspólnoty nie ulegało zmianie.

W przypadku nowych osadników, trudno określić, w którym momencie (od osadzenia we wsi) nadział kmiecia był włączany do mienia samorządu. Nowi osadnicy mieli prawo do zwolnienia z czynszu na „lata wolnizny", czyli okres potrzebny do zagospodarowania ziemi (wynosił on od 2 do 24 lat). Wydaje się więc, że do momentu, gdy nadział nie był wykorzystywany przez mieszkańców gminy, nie stanowił mienia samorządu. Nie stanowił bowiem - zgodnie z definicją Inglota - ziemi niezajętej ani ziemi ornej po zbiorach ${ }^{30}$.

Według koncepcji K. Tymienieckiego, wspólne użytki przysługiwały przede wszystkim panu gruntowemu, a dopiero potem wspólnocie kmieci. Mógł on więc swobodnie dysponować pastwiskami i drewnem z obszaru wsi i nie podlegał pod tym względem, żadnym regulacjom prawnym. Zdaniem tego autora, pan miał nawet prawo dopuścić obcych kmieci z obszarów granicznych do wspólnych użytków w jego $\mathrm{wsi}^{31}$.

Powiększenie dóbr samorządu zależało od samego feudała. Ze względów gospodarczych lepiej było by wieś miała tylko jednego właściciela, a nie była podzielona pomiędzy kilku panów ziemskich. W drugim wypadku wspólnota użytków przysługiwała ogółowi chłopów w granicach terytorium wsi, bez względu na to czyimi byli kmieciami. Niekiedy szachownica pól obejmowała tereny innej wsi, prowadząc tym samym do zawarcia umowy dotyczącej użytkowania pastwisk przez kmieci z obu wsi. Umowa ta nie była zawierana pomiędzy samorządami gmin ani wspólnotami chłopów, ale między ich właścicielami ${ }^{32}$.

Charakterystyczne dla średniowiecznej gminy, koncepcja własności pańskiej i wspólnego użytkowania ziemi, jako mienia samorządu wiejskiego, nie dają odpowiedzi na szereg szczegółowych pytań, dotyczących m.in. prawa własności do stawianych we wsi karczmy, spichlerza, targu, czy kwestii właścicieli narzędzi rolniczych, używanych, w ramach pomocy sąsiedzkiej, przez kilka gospodarstw.

Nadzór w średniowiecznym państwie polskim wynikał z samego systemu feudalnej zależności, jakiej podlegały stany społeczne i instytucje

\footnotetext{
30 Ibidem.

31 K. Tymieniecki, Procesy twórcze, s. 224-226.

32 Ibidem, s. 228.
} 
przez nie tworzone. W ustroju poddaństwa i przypisania do ziemi, życie chłopów podlegało ścisłej regulacji i kontroli ze strony pana feudalnego, jako przedstawiciela władzy państwowej oraz jedynego właściciela ziemi i ludności na niej zamieszkałej.

W początkowym okresie nadań ziemskich, wpływ feudałów na stosunki zachodzące między nimi a ludnością zależną mógł być ograniczony wolą monarchy. Wraz z upowszechnieniem stosunków poddańczych możliwości kontroli ogromnej liczby panów ziemskich znacznie się zmniejszyły $^{33}$. Z czasem jedynym kryterium, obejmującym działalność wspólnoty wiejskiej stała się wola jej pana. Sytuacja uległa zmianie z chwilą ujednolicenia przepisów prawnych dotyczących świadczeń i powinności chłopów, a zwłaszcza przez wprowadzenie do wsi ustawodawstwa niemieckiego.

Do XIII w. zbędny był (ze względu na małe upowszechnienie trójpolówki) nadzór nad przebiegiem prac na roli i produkcją chłopską. Nadzór nad funkcjonowaniem jednostek wiejskich, ograniczał się, w tym okresie do kontroli zbioru podatków i wywiązywania się z zadań zleconych odgórnie przez władcę. Wraz z rozwojem gmin i komplikowaniem się struktury wsi, zakres kurateli nad działalnością chłopów i tworzonych przez nich instytucji musiał gwałtownie ulec zwiększeniu.

Kontrola nad samorządem wsi opierała się na usankcjonowanym prawnie przymusie. Kryterium nadzoru, w ramach którego można było stosować siłę, jako metodę egzekwowania powinności gminy wiejskiej, była zgodność z przepisami prawnymi. Podstawowym aktem prawnym, do którego się odnoszono był dokument lokacyjny, określający prawa i obowiązki mieszkańców wspólnoty samorządowej.

Zdaniem S. Inglota, ustrój feudalny umacniał pozycję pana ziemskiego, determinując organizację administracji wiejskiej od jego woli. Regulacja i nadzór nad wsią wyrażała się zarówno w wybraniu dworu na miejsce pracy urzędników administracyjno-gospodarczych, jak i w samym ich wyborze. Pełnienie jakiejkolwiek funkcji we wsi, uzależnione było od jej właściciela. Kwestia ta dotyczyła przede wszystkim sołtysa, ale także samych ławników, których kandydatura musiała uzyskać poparcie pana. Działalność samorządu, a zwłaszcza postępowanie poszczególnych funkcjonariuszy sądu wiejskiego nie mogło szkodzić interesom pana. Kontrola nad ławnikami sprowadzała się w takim wypadku do usu-

33 S. Inglot, Historia gospodarcza, s. 91; S. Inglot, Historia społeczna, s. 114. 
nięcia z urzędu nielojalnego sędziego albo wypłaty panu rekompensaty pieniężnej $^{34}$.

Sołtys jako mieszkaniec wsi, a zarazem przewodniczący sądu wiejskiego, nie podlegał jego sądownictwu. Organem kontrolującym działalność sołtysa był tzw. sąd leński, w skład którego wchodzili inni sołtysi i wójtowie, pod przewodnictwem pana ziem lub jego zastępcy ${ }^{35}$.

Zdaniem A. Świętochowskiego sołtysi byli sądzeni albo przez innych sołtysów, albo przez najwyższy sąd niemiecki. Ze względu na to, że wiązało się to $\mathrm{z}$ trudnościami często stawali przed sądem kasztelańskim bądź biskupim. $Z$ czasem zaś podlegali sądownictwu pana feudalnego lub jego zastępcy. W wyjątkowych okolicznościach, gdy mogli być sądzeni przez ławę wiejską ${ }^{36}$. Ta rozbieżność instytucjonalna związana była z faktem, iż do połowy XIV w. brak było na ziemiach polskich nadrzędnego sądu prawa niemieckiego.

W przypadku wątpliwości sądy wiejskie zwracały się o wyjaśnienie wprost do Magdeburga lub Halli, gdzie znajdywały się najwyższe ich instancje. Dopiero w 1365 r. Kazimierz Wielki powołał osobny trybunał zajmujący się kwestiami funkcjonowania prawa niemieckiego na ziemiach polskich. Instytucja ta została jednak powołana zbyt późno, a wraz z rozpoczęciem się procesu likwidacji sądów chłopskich (1423 r.) stała się właściwie niepotrzebna ${ }^{37}$. Do tego czasu ze względu na znaczne koszta i trudności w zwołaniu sądu leńskiego z woli panów ziemskich jurysdykcja nad sołtysami mogła zostać przekazana innym instytucjom, bądź też być sprawowana przez nich osobiście.

Zdaniem K. Modzelewskiego, ówczesne państwo zmuszone było do działania w trybie administracyjnego przymusu. Tylko w ten sposób, bowiem mogło ono dotrzeć bezpośrednio do płatników danin ${ }^{38}$. Odgórny system ściagania danin był raczej, wynikiem praktycznego podejścia do

34 S. Inglot, Historia społeczna, s. 115; por. Historia chłopów, s. 21.

35 S. Wójcik, op. cit., s. 40-41; J. Bardach, op. cit., s. 139; M. Gończar, op. cit., s. 12.

36 A. Świętochowski, Historia chłopów polskich w zarysie, Warszawa 1947, S. 52 .

37 A. Świętochowski, op. cit., s. 52. Szerzej: F. Piekosiński, Przywilej króla Kazimierza Wielkiego w przedmiocie założenia sqdu wyższego prawa niemieckiego, ,Rozprawy Akademii Umiejętności Wydziału Historyczno-Filozoficznego” 1898, t. 10.

38 K. Modzelewski, Chtopi, s. 128; K. Modzelewski, Organizacja gospodarcza państwa piastowskiego X-XIII w., Wrocław 1975, s. 136. 
kwestii świadczeń i ustalonego prawa zwyczajowego, niż dążeń centralistycznych władzy państwowej ${ }^{39}$.

Mimo władzy nad mieszkańcami wsi pan nie zawsze był w stanie wyegzekwować należne mu świadczenia, nie mówiąc już o opłatach należnych innym instytucjom (państwu, Kościołowi). Przy dużej ilości różnorodnych danin ściagganie ich przez pana, sołtysa, czy samą wspólnotę wiejska, stanowiłoby zbyt wielkie obciążenie. $Z$ tego powodu władza państwowa wprowadziła odgórny system skutecznej kontroli nad wywiązywaniem się ze świadczeń feudalnych.

Nadzór w okresie piastowskim oparty był o ewidencję ludności. Rejestry podatkowe sporządzane były przez urzędników państwowych na podstawie wiejskich spisów kmieci ${ }^{40}$. Dzięki urzędnikom państwowym, posiadającym uprawnienia do użycia siły, aparat władzy zdołał przeniknąc do społeczności lokalnych, a powołując się na prawo zwyczajowe zapewnił sobie ich współpracę. Wraz z rozwojem osadnictwa i tworzeniem nowych wsi, wzrastało zapotrzebowanie na poborców, pełniących w przypadku krnąbrnych chłopów dodatkowo funkcje kontroli sądowej i policyjnej.

Zorganizowane systemy kontroli wywodziły się z wczesnego okresu państwa polskiego i początkowo obejmowały wyłącznie ludność niewolną i nieswobodną. We wczesnym średniowieczu organizacja tej grupy opierała się na systemie setno-dziesiętnym. Charakteryzował się on zgrupowaniem ludności w określone jednostki (podstawowe dziesiątki i nadrzędne setki), podległe nadzorowi administracyjnemu urzędników rekrutowanych najczęściej z grupy osób przypisanych do ziemi ${ }^{41}$.

Skupiając się na wczesnym systemie nadzoru nad ludnością poddańczą, Inglot nie poświęca uwagi organizacji grodowo-kasztelańskiej, będącej instrumentem przymusu administracyjnego w okresie zmian ustrojowych $^{42}$. Problem nadzoru sprowadzony został przez niego wyłącznie do kontroli nad świadczeniami, która w przypadku danin, obejmowała ich ja-

39 Świadczy o tym fakt istnienia instytucji poborcy we wcześniejszej formie życia wspólnotowego, a mianowicie w opolu. Por. K. Modzelewski, Chtopi, s. 43, 188-189, 192; K. Modzelewski, Organizacja opolna w Polsce piastowskiej, „Przegląd Historyczny" 1986, z. 2, s. 216-217.

40 K. Tymieniecki, Procesy twórcze, s. 331.

41 Historia chłopów, s. 30-31; K. Modzelewski, Organizacja gospodarcza, s. 150. Por. K. Buczek, O chłopach w Polsce piastowskiej, cz. I, „Roczniki Historyczne” 1974, s. 54-55.

42 Szerz. K. Modzelewski, Chłopi, s. 130, 141-142. 
kość i ilość, w przypadku wszystkich rodzajów dotyczyła terminu wywiązywania się z obowiązku ich uiszczania. Autor lakonicznie stwierdza, iż nadzór ten należał do funkcjonariuszy administracyjno-gospodarczych ${ }^{43}$.

Kontrola nad ludnością wolną na przełomie XII i XIII w. została oparta na jednolitym systemie grodowym i prawie kasztelańskim. System ten mieścił w sobie: zarząd gospodarczy (zajmujący się egzekwowaniem świadczeń i posług, gospodarowaniem zasobami), ewidencję i nadzór policyjny nad ludnością wiejską, pozostając w gestii samego samorządu nadzór nad wiejskim rolnictwem ${ }^{44}$.

Nie wydaje się jakoby agenda grodowo-kasztelańska wywodziła się z wcześniejszej organizacji ludności niewolnej. Jedynym zachodzącym między nimi podobieństwem jest ich przymusowy charakter. Obie organizacje, jako systemy centralnego nadzoru władzy państwowej, przyzwyczaiły ludność wiejską do pośrednictwa (między nią a władcą) wyznaczonych odgórnie urzędników.

Mówiąc o kontroli nad samorządem i stosowaniu przymusu względem jego funkcjonariuszy, nie sposób nie wspomnieć istniejącym ówcześnie, opartym na prawie karnym nadzorze władz sądowych. W państwie piastowskim kary za przestępstwa były ściśle związane z przynależnością społeczną. Wraz z rozwojem prawa karnego, pojęcie kary ewoluowało i rozszerzało się w kierunku dostosowania jej do przestępstwa. Przestępstwa dokonane w tym okresie mogły być ścigane z urzędu lub dochodzone na drodze prywatnej. Ten drugi sposób miał charakter uprawomocnionego odwetu, a to dzięki ówczesnej instytucji wróżd, czyli tzw. „,wojen prywatnych". Do przestępstw ściganych z urzędu zaliczano: występki przeciwko panującemu, państwu, religii państwowej, ustrojowi i porządkowi publicznemu. Kary za te przestępstwa w okresie niestabilności polityki wewnętrznej i zewnętrznej, należały do najbardziej surowych, ponieważ godziły w jednolitość i władzę ówczesnego państwa.

W okresie silnej władzy monarszej instytucją stojącą na straży bezpieczeństwa publicznego i ustroju, był mir (tzw. ręka pańska). Mir miał charakter miejscowy - obejmował określone terytorium lub osobowy dotyczył określonej kategorii osób. Za złamanie miru obowiązywały wysokie, bo potrójne kary, uwzględniające zadośćuczynienie osobom prywatnym, opłatę państwową i sądową ${ }^{45}$.

43 S. Inglot, Historia społeczna, s. 113-114.

44 K. Modzelewski, Organizacja gospodarcza, s. 140-141.

45 Por. S. Inglot, Historia społeczna, s. 178-181; J. Bardach, op. cit., s. 152-153. 
Zagadnienia odpowiedzialności kmieci za popełnione przestępstwo zostały uregulowane statutami kaziemrzowskimi. Umocniły one indywidualną odpowiedzialność karną, a ograniczyły możliwość przeniesienia kary na krewnych skazanego. Według ówczesnego prawa odpowiedzialność osobista dotyczyła zawsze przypadku kary śmierci i kary mutylacyjnej (okaleczenia), natomiast kary pieniężne i konfiskaty dóbr mogły obejmować krewnych skazanego, gdy on sam nie mógł ich uiścić ${ }^{46}$.

W literaturze dotyczącej średniowiecznych wspólnot wiejskich często występuje termin odpowiedzialności zbiorowej. W wypadku nie wywiązywania się z obowiązków, jakie spoczywały na całej wsi, jako wspólnocie (daniny, pogoń, ślad, krzyk) kara obejmowała wszystkich mieszkańców gminy. Zasada ta była pozostałością po wspólnotach opolnych, gdzie była wyrazem jedności wspólnoty. We wsiach opartych na ustroju feudalnym taka forma pełniła, raczej funkcję środka nacisku niż rzeczywistej kary. Widmo zbiorowej odpowiedzialności było często wykorzystywane przez panów do wywołania presji na chłopów, w celu szybkiego wykrycia sprawcy lub ukrócenia buntów, wobec wysokich świadczeń ${ }^{47}$. Ze względu na charakter wykroczenia i osobę przestępcy w średniowiecznym prawie wyróżniano cztery podstawowe grupy kar: publiczne, prywatne (obejmujące ustalone zwyczajowo wynagrodzenie krzywdy pokrzywdzonemu lub jego rodzinie), zwykłe i kwalifikowane (z torturami). Do najczęstszych form wymierzenia sprawiedliwości w państwie piastowskim należały: kara śmierci, wywołanie (śmierć prawna), niewola, wygnanie, kara pieniężna, konfiskata dóbr i okaleczenie.

Do form zapobiegających przestępczości i ułatwiających nadzór nad mieszkańcami gminy, zaliczano zaś: uwięzienie, rękojemstwo i zakład (ustalany zapobiegawczo przez właściciela ziem, obawiającego się przestępstwa $)^{48}$. W przypadku dóbr kościelnych skuteczną i powszechną karą za odmowę wywiązywanie się ze świadczeń były klątwy i ekskomunika.

Można powiedzieć, iż ówczesna kontrola ludności wiejskiej i tworzonych przez nią organów wynikała ze swoiście rozumianej troski panów feudalnych o porządek i bezpieczeństwo publiczne. To właśnie średniowieczne urzędy nadzorcze i szczegółowe prawo karne gwarantowały skuteczny pobór świadczeń i funkcjonowanie społeczeństwa stanowego. $\mathrm{Z}$ jednej strony, system nadzoru, tłumiąc wszelkie wyrazy sprzeciwu

46 J. Bardach, op. cit., s. 156-157.

${ }^{47}$ Por. Historia chlopów, s. 34; K. Modzelewski, Chłopi, s. 177.

${ }^{48}$ Historia chłopów, s. 42; J. Bardach, op. cit., s. 159-163, 165. 
chłopów, przyczynił się do ograniczenia ich działalności samorządowej, z drugiej, wzbudził w warstwie chłopskiej poczucie odrębności i świadomość własnych praw.

Na skutek nowatorskich regulacji - zwłaszcza przejścia wsi na prawo niemieckie - sytuacja społeczności wiejskiej uległa znacznej poprawie. Wśród korzyści z tych przekształceń wymienia się: przebudowę gospodarki wsi, związanie jej z rynkiem lokalnym oraz zmianę pozycji chłopa. Nowa forma osadnictwa miała istotne znaczenie dla stworzenia polskiej wsi czynszowej polepszenia sytuacji gospodarczej i prawnej chłopów, ale także zwiększyła dochody panów. Przede wszystkim funkcjonowanie wsi na prawie niemieckim dało własnym mieszkańcom prawo do samorządu $^{49}$. Faktem jest, bowiem to, iż w ówczesnych wsiach opartych na prawie polskim, gdzie prawo nadziału, jak i wysokość świadczeń były niesprecyzowane, a jurysdykcja opierała się na woli pana, sytuacja chłopów była gorsza niż we wsiach na prawie niemieckim. Dokonujące się zmiany ustrojowe były skutkiem lokacji gmin na prawie niemieckim ${ }^{50}$.

Osadnictwo na prawie niemieckim stało się krokiem naprzód w stosunku do zwyczajowego „obyczaju wolnych gości”. W praktyce, stało się ono wielką reformą ówczesnego rolnictwa. Gwarantowało ono wolność osobistą wszystkim osadnikom, bez względu na pochodzenie społeczne, jedną opłatę pieniężna, zamiast szeregu uciążliwych danin i robocizny, prawo opuszczenia wsi oraz nadział oddany chłopu w użytkowanie.

Mówiąc o wolności chłopskiej, należy pamiętać, że pojęcie to w okresie upowszechniania się zasad feudalizmu było odległe od późniejszego, a zwłaszcza współczesnego nam rozumienia praw wolnościowych. Bez adekwatnej definicji można dojść do sprzeczności w rozumowaniu, wynikającego z dylematu mówienia o wolności chłopa, gdy pozostaje on w zależności feudalnej względem swego pana. Trzeba wyraźnie stwierdzić, iż nie było w państwie piastowskim wolnych chłopów. Ówczesna wolność wyrażała się, bowiem w pełnym prawie do własności (przede wszystkim ziemskiej), które stanowiło przywilej prawa rycerskiego. Chłop feudalny

49 Historia chłopów, s. 21; J. Bardach, op. cit., s. 47; M. Gończar, op. cit., s. 12.

50 Lokacja na prawie niemieckim, nie oznaczała kolonizacji niemieckiej - zakładania wsi przez chłopów niemieckich. Wyrażała się ona w przejściu wsi z prawa rodzimego na prawo zachodnie; Historia chłopów, s. 23-25; Por. R. Grodecki, S. Zachorowski, J. Dąbrowski, Dzieje Polski średniowiecznej, t. 1, Kraków 1995, s. 207; K. Tymieniecki, Osobiste i terytorialne poddaństwo chłopów w wiekach średnich, „Kwartalnik Historyczny" 1957, z. 2, s. 273. 
zawsze był „czyimś” chłopem, zawsze był komuś poddany. Jego „wolność chłopska" ograniczała się zaś do: siedzenia na własnym, tzn. danym w użytkowanie gruncie i możliwości dziedziczenia go przez potomków ${ }^{51}$, korzystania z określonych prawem zwolnień od świadczeń feudalnych, możliwości przenoszenia się z miejsca na miejsce i podlegania sądownictwu wiejskiemu. Inaczej można stwierdzić, iż za istotę wolności chłopów w okresie średniowiecza zwykło się uznawać niezależność od czyjejkolwiek władzy dominialnej lub możność jej zamiany w określonych prawem (zwyczajowym) okolicznościach ${ }^{52}$.

Okres działalności samorządów wiejskich sprzyjał umocnieniu pozycji ówczesnych kmieci i samych gmin, jako konkurencyjnych jednostek terytorialnych o silnej pozycji w stosunkach handlowych. Dzięki przemianom ustrojowym chłopi uzyskali możliwość ochrony własnych spraw w ramach struktur samorządowych oraz szereg uprawnień (okres wolenizny, wolność po wywiązaniu się z określonych obowiązków, pomocne). Przede wszystkim zyskali oni pewność, że po uiszczeniu stałej opłaty czynszowej, będą mogli samodzielnie dysponować resztą zysków z nadziału $^{53}$.

Ówczesne zmiany ustrojowe sprawiły, ze nawet małorolni i bezrolni chłopi, objęci znikomą ochroną, zajęli stałe i określone miejsce w nowej strukturze społecznej. Na fakt ten wskazuje zdolność chłopów do opłacania czynszów pieniężnych, głównie za sprawą rozwoju targów (stanowiących wewnętrzny rynek - miejsce kontaktów i związków społecznych) ${ }^{54}$.

Upowszechnienie wsi czynszowej i samorządnych struktur gminnych przyniosło korzyści nie tylko kmieciom, ale i władcom ziem. Stworzenie samorządu wiejskiego leżało również w interesie państwowym, wskazuje na to fakt, iż stanowiło ono element celowej, gospodarczej aktywności prowadzonej przez władze państwa piastowskiego ${ }^{55}$.

Wraz z rozszerzeniem prawa niemieckiego na wsie rodzime, panowie feudalni utracili część zwierzchnictwa nad polską wsią. Pomimo tego, iż samorządy, znosząc wcześniejsze szczegółowe i uciążliwe świadczenia (wynikające z prawa książęcego), pozbawiły feudałów możliwości sądze-

51 Por. K. Buczek, O chłopach w Polsce piastowskiej, cz. II, „Roczniki Historyczne" 1975 , s. 4-5.

52 K. Buczek, O chłopach, cz. I, s. 91; Por. K. Modzelewski, Chłopi, s. 228-229.

53 M. Gończar, op. cit., s. 13.

54 K. Tymieniecki, Historia chłopów, s. 498.

55 Ibidem; R. Grodecki, Dzieje, t. 2, s. 155. 
nia kmieci, reforma wsi bardziej wzmocniła ich pozycję. Wprowadzenie czynszu pieniężnego sprawiło, iż dochody właścicieli ziemskich znacznie wzrosły. Działo się to dzięki temu, że nie musieli oni szukać rynków zbytu dla produktów rolnych, których sprzedaż stała się problemem kmieci. Ponadto w nowej sytuacji, w zamian za uprawnienia stanowienia chłopów o sobie, władca zyskiwał dobrze wyposażonych wojowników, gotowych do obrony ziem przed wrogiem.

W takiej sytuacji chłopi szukając rynków zbytu kierowali się wyłącznie własnym, najlepiej rozumianym interesem. Te nowe doświadczenia i częściowa swoboda w decydowaniu o swoim losie i użytkowanym gospodarstwie, zwróciły uwagę kmieci na problemy całej wspólnoty samorządowej. Wzmocnienie pozycji samorządu stanowego wsi było mocno skorelowane z rozwojem gospodarczym gmin wiejskich, co miało także wpływ na siłę identyfikacji chłopów z własnym stanem.

Samorząd stanowy, jako instytucja o kompetencjach sądowniczych i administracyjnych, przyczynił się w okresie średniowiecza do wychowania społecznego, rozwoju demokracji (w wymiarze pierwotnym, stanowym), jak również ochrony godności człowieka, a zwłaszcza grup mających marginalny wpływ na ówczesne życie polityczne i społeczne w tym zwłaszcza chłopów. Był szkołą obywatelskiego wychowania, a przez realizowanie zasad wolności i partycypacji przyczynił się do rozszerzenia zakresu uprawnień gmin, gwarantował zabezpieczenie oraz realizację praw poszczególnych mieszkańców wspólnoty.

Elementy funkcjonowania samorządu wiejskiego w średniowieczu mogą stanowić pewne odniesienie w kwestii administracji lokalnej czasów nam współczesnych. Ze względu na czynnik gospodarczy oraz ścisłą kontrolę funkcjonowanie tej instytucji sprawdzało się w trudnym okresie średniowiecznych reform ustrojowych. Świadczy to o tym, że zagadnienie decentralizacji w jej wymiarze administracyjnym i gospodarczym jest wpisane w funkcjonowanie państwa.

Powyższe rozważania dotyczące uposażenia gospodarczo-finansowego samorządu stanowego wykazały, iż to właśnie władztwo nad majątkiem stanowi podstawę zabezpieczenia interesów gminy w tym praw jej poszczególnych mieszkańców, gwarantując tym samym jej istnienie i rozwój. Kwestia ta, może stać się wskazówką dla tych wszystkich współczesnych instytucji lokalnych, które zmuszone są odnaleźć swój kształt w sytuacji szerokich zmian politycznych, prawnych, społecznych i gospodarczych. 
Na podstawie dotychczasowych doświadczeń gmin w kwestii zarządu nad własnym mieniem, praktyka zdaje się potwierdzać rozważania teoretyczne. Większość samorządów dzięki samodzielności administracyjnej w gospodarowaniu majątkiem - zwłaszcza dzięki zyskowi finansowemu, który jest efektem tego zarządu - zwiększa swoje poczucie podmiotowości i obywatelstwa, umacniając jednocześnie więzi między mieszkańcami wspólnoty.

Samorząd był kwestią ważną i sprawdzającą się w okresie rozwoju średniowiecznej demokracji monarchistycznej. Jest taki również teraz, w okresie poszukiwania nowych rozwiązań dla samorządu i jego funkcjonowania w perspektywie integracji europejskiej. Stając wobec problemu skomplikowanej struktury współczesnych instytucji samorządowych nie wolno uchylać się od podejmowania prób w budowaniu odpowiedzi na trudne pytania o początkowy okres funkcjonowania samorządu w jego zinstytucjonalizowanej formie. Nawet więcej - należy badać je pomimo trudności, jakie niesie ze sobą nieliczny i niekompletny materiał źródłowy. Z historii samorządu bowiem należy korzystać - to znaczy wyciagać z niej wnioski - by móc sprostać konieczności unowocześnienia instytucji lokalnych.

\section{Bibliografia}

Bardach J., Leśnodorski B., Pietrzak M., Historia ustroju i prawa polskiego, Warszawa 1998.

Buczek K., O chłopach w Polsce piastowskiej, cz. I, „Roczniki Historyczne” 1974, s. $51-105$.

Buczek K., O chłopach w Polsce piastowskiej, cz. II, „Roczniki Historyczne” 1975, s. $1-79$.

Buczek K., Uwagi o prawie chtopów do ziemi w Polsce piastowskiej, „Kwartalnik Historyczny" 1957, z. 3, s. 86-99.

Gończar M., Samorzad wsi historia i nowe możliwości, Warszawa 1990.

Grabski S., Myśli o dziejowej drodze Polski, Warszawa 1989.

Grodecki R., Zagadnienia feudalizmu w Polsce, Kraków 1930.

Grodecki R., Zachorowski S., Dąbrowski J., Dzieje Polski średniowiecznej, t. 1-2, Kraków 1995.

Heck R., Okres gospodarki czynszowej (od połowy XIII do schytku XV w.), w: Historia chtopów polskich, t. 1, pod red. S. Inglota, Warszawa 1970.

Historia chłopów polskich, pod red. S. Inglota, Wrocław 1992. 
Inglot S., Historia gospodarcza. Zarys dziejów: starożytnych, średniowiecznych, nowożytnych, nowoczesnych, Wrocław 1949.

Inglot S., Historia społeczna i gospodarcza średniowiecza, Wrocław 1949.

Łowmiański H., Przemiany feudalne wsi polskiej do 1138 r., „Przegląd Historyczny” 1974, z. 3, s. 437-461.

Modzelewski K., Chłopi w monarchii wczesnopiastowskiej, Wrocław 1987.

Modzelewski K., Organizacja gospodarcza państwa piastowskiego X-XIII w., Wroclaw 1975.

Modzelewski K., Organizacja opolna w Polsce piastowskiej, „Przegląd Historyczny” 1986, z. 2, s. 177-219.

Piekosiński F., Przywilej króla Kazimierza Wielkiego w przedmiocie założenia sqdu wyższego prawa niemieckiego, „Rozprawy Akademii Umiejętności Wydziału Historyczno-Filozoficznego" 1898, t. 10.

Świętochowski A., Historia chłopów polskich w zarysie, Warszawa 1947.

Tymieniecki K., Historia chłopów polskich, t. 1, Warszawa 1965.

Tymieniecki K., Osobiste i terytorialne poddaństwo chłopów w wiekach średnich, „Kwartalnik Historyczny” 1957, z. 2, s. 245-276.

Tymieniecki K., Procesy twórcze formowania się społeczeństwa wiekach średnich, Warszawa 1921.

Tymieniecki K., Z metodyki nad starożytnościami słowiańskimi, „Przegląd Historyczny" 1948, s. 7-21.

Wójcik S., Samorzqd terytorialny w Polsce w XX wieku. Myśl samorzqdowa Historia i współczesność, Lublin 1999.

\section{Summary}

As a result of expansion of the feudal system, as well as due to an intensified process of colonization and economical and legal transformations, at the turn of the $12^{\text {th }}$ and $13^{\text {th }}$ centuries there were formed estate representative institutions. The local estate countryside administration was established as a direct consequence of the fact that some of the rights of the landowners were transferred onto communal units. The functioning of the local countryside administration was limited by law and monitored by the state authorities. Its salaries resulted partly from the concession on the part of a land proprietor, partly from the contemporaneous customary case law. The local countryside administration did not own any property as such; it could only be lent under the law of common use. The control of the local countryside authorities was based on a legally sanctioned constraint. The criterion for the supervision of this institution was its compliance with the legal norms, particularly with a location document of a given country commune. 